\title{
PENGETAHUAN DAN SIKAP IBU DALAM MENGHADAPI \\ PRE MENOPAUSE DI KELURAHAN BARU LADANG \\ BAMBU KECAMATAN MEDAN TUNTUNGAN
}

\author{
Oleh: \\ Zulkarnain Nasution \\ Universitas Darma Agung, Medan \\ E-mail: \\ zulkarnain@darmaagung.ac.id
}

\begin{abstract}
ABSTRAK
Pre menopause merupakan hal yang sangat dikhawatirkan dan ditakuti oleh setiap wanita. Perubahan yang terjadi selama masa pre menopause akan menimbulkan produksi hormon estrogen menurun disertai dengan keluhan psikologi maupun fisik, yang ditandai dengan siklus haid yang tidak teratur dengan perdarahan haid yang memanjang dan ukuran perdarahan banyak yang disertai nyeri. Seiring dengan fungsi organ tubuh yang menurun seorang wanita akan mengalami kecemasan yang akan mempengaruhi hubungan dengan suami maupun lingkungan sosial yang mengakibatkan kepercayaan diri seorang wanita berkurang. Penelitian ini bertujuan untuk mengetahui pengetahuan dan sikap ibu dalam menghadapi pre menopause. Jenis penelitian deskriptif. Populasi dalam penelitian ini adalah 175 orang ibu-ibu pre menopause. Sampel penelitian ini adalah 64 orang dengan teknik pengambilan sampel simple random sampling. Hasil penelitian menunjukkan pengetahuan ibu dalam menghadapi pre menopause kurang dan sikap ibu dalam menghadapi pre menopause positif. Pengetahuan ibu kurang karena disebabkan ibu belum pernah mendapatkan informasi tentang pre menopause dan belum pernah mendapatkan penyuluhan kesehatan tentang pre menopause. Sikap ibu yang positif disebabkan karena ibu mampu mengalihkan perasaan yang tidak menyenangkan ke hal-hal positif dengan cara melakukan berbagai aktifitas, dan menganggap bahwa hal yang dialami selama pre menopause merupakan hal wajar yang akan dialami oleh setiap wanita. Diharapkan kepada petugas kesehatan agar memberikan penyuluhan kesehatan tentang pre menopause, dan kepada ibu premenopause diharapkan proaktif untuk mencari informasi yang berkaitan dengan pre menopause.
\end{abstract}

Kata kunci : Pengetahuan, Sikap, Ibu, Pre Menopause, Medan.

\section{PENDAHULUAN}

\subsection{Latar Belakang}

Seiring dengan peningkatan usia, banyak proses perkembangan dan pertumbuhan pada tubuh manusia. Namun pada suatu saat pertumbuhan dan perkembangan itu akan terhenti pada suatu tahapan sehingga berikutnya akan terjadi banyak perubahan. Perubahan tersebut paling banyak terjadi pada wanita karna pada proses menua terjadi suatu fase yaitu fase menopause. Sebelum terjadi fase 
menopause terlebih dahulu terjadi fase premenopause dimana fase menopause ini terjadi peralihan dari masa subur menuju masa tidak adanya pembuahan (anovulatior). Secara medis istilah premenopause adalah suatu kondisi fisiologis pada wanita yang telah memasuki proses penuaaan (aging), yang ditandai dengan menurunnya kadar hormonal estrogen dari ovarium yang sangat berperan dalam hal reproduksi dan seksualitas. Pada masa premenopause wanita mengalami perubahan endokrin, somatik, dan psikis, yang terjadi pada akhir masa subur atau reproduktif. Pada masa ini wanita menyesuaikan diri dengan menurunnya produksi hormon yang dihasilkan indung telur/ovarium. Dampaknya bagi wanita sangat berfariasi, tergantung pada banyak faktor terutama lingkungan sosial dan keluarga. Premenopause seringkali mempunyai dua pengertian yaitu satu atau dua tahun segera sebelum menopause atau pada semua periode reproduktif sebelum menopause. Sindrom premenopause dialami oleh banyak wanita hampir diseluruh dunia sekitar 70-80\% wanita Eropa, 60\% di Amerika, 57\% di Malaysia, $18 \%$ di China, dan 10\% di Jepang dan Indonesia. Dari beberapa data tampak bahwa salah satu faktor dan perbedaan jumlah tersebut adalah karena pola makannya. Wanita Eropa dan Amerika mempunyai estrogen yang lebih banyak dari pada Asia. Ketika terjadi menopause wanita Eropa dan Amerika estrogennya menurun drastis dibanding wanita Asia yang kadar estrogennya moderat. Penurunan kadar estrogen tersebut sering menimbulkan gejala yang sangat menggangu aktivitas kehidupan para wanita.

Seperti telah kita pahami bahwa premenopause menjadi momok tersendiri bagi wanita. Kendati hal ini alamiah terjadi pada semua wanita, namun efek sampingnya banyak mempengaruhi keharmonisan rumah tangga bila tidak siap menghadapinya. Premenopause menimpa wanita pada usia menjelang 40 tahun keatas pada masa ini terjadi ketidakteraturan haid. Masalah yang timbul akibat premenopause ini disebut dengan syndrome premenopause meliputi hot flushes (semburan panas dari dada hingga wajah), nigh sweat (berkeringat dimalam hari), dryness vaginal (kekeringan vagina), penurunan daya ingat, insomnia (susah tidur), depresi (rasa cemas), fatigue (mudah capek), penurunan libido, drypareunia (rasa sakit ketika berhubungan seksual) dan incontinence urinary (beser). Munculnya gejala yang menyertai sindrom premenopause ini dapat menyebabkan berbagai keluhan pada wanita, dan munculnya gejala ini ditanggapi dengan berbeda-beda pula. Akibat perubahan dari gejala yang menyertai sindrom premenopause ini yang berupa haid tidak teratur, otomatis terjadi perubahan pada organ reproduksi wanita. Perubahan fungsi indung telur akan mempengaruhi hormon yang kemudian memberikan pengaruh pada organ tubuh wanita pada umumnya. Aspek psikologi yang terjadi pada wanita yang mengalami premenopause amat berperan penting dalam kehidupan sosialnya dan tidak dapat dipisahkan antara aspek organ-biologis, 
psikologis, sosial, budaya dan spiritual dalam kehidupan. Gejala dan tanda psikologis dari sindrom premenopause adalah daya ingatan menurun, kecemasan, mudah tersinggung, stress dan depresi. Beberapa wanita yang memasuki masa premenopause menyambutnya dengan biasa mereka menganggap kondisi ini sebagai bagian dari siklus hidupnya, banyak juga wanita yang mengeluh bahwa dengan datangnya premenopause mereka akan menjadi cemas. Kecemasan yang muncul pada wanita yang mengalami sindrom premenopause sering dihubungkan dengan adanya kekhawatiran dalam menghadapi suatu situasi yang sebelumnya tidak pernah dikhawatirkan. Wanita seperti ini sangat sensitif terhadap pengaruh emosional akibat fluktuasi hormon. Umumnya mereka tidak mendapat informasi yang benar sehingga yang dibayangkanya adalah efek negatif yang akan dialami setelah memasuki masa premenopause dan menopause. Mereka cemas menjelang berakhirnya era reproduksi yang berarti berhentinya nafsu seksual dan fisik. Apa lagi menyadari dirinya akan menjadi tua, yang berarti kecantikanya akan memudar. Seiring dengan hal itu, faliditas dan fungsi organ tubuhnya akan menurun. Hal ini akan menghilangkan kebanggaanya sebagai wanita dan dikhawatirkannya akan mempengaruhi hubungannya dengan suami maupun lingkungan sosialnya. Selain itu, usia ini sering dikaitkan dengan timbulnya penyakit kanker atau penyakit lain yang sering muncul pada saat wanita memasuki usia premenopause. (Atikah 2010).
Berdasarkan

survei pendahuluan yang dilakukan peneliti di Kelurahan Baru Ladang Bambu Kecamatan Medan Tuntungan didapatkan 3 dari 5 orang ibu tidak mengetahui tentang masa premenopause. Oleh karena itu penulis melakukan penelitian tentang pengetahuan dan sikap ibu dalam menghadapi premenopause di Kelurahan Baru Ladang Bambu Kecamatan Medan Tuntungan, dan diharapkan dengan pengetahuan dan sikap yang baik terutama bagi ibu premenopause.

\subsection{Rumusan Masalah}

Rumusan masalah penelitian ini adalah bagaimana pengetahuan dan sikap ibu dalam menghadapi premenopause di Kelurahan Baru Ladang Bambu Kecamatan Medan Tuntungan.

\subsection{Tujuan Penelitian}

Tujuan penelitian ini adalah untuk mengetahui pengetahuan dan sikap ibu dalam menghadapi premenopause di Kelurahan Baru Ladang Bambu Kecamatan Medan Tuntungan.

\subsection{Manfaat Penelitian}

1. Bagi Peneliti

Penelitian ini sebagai sarana untuk belajar menerapkan teori yang telah diperoleh dalam bentuk nyata dan meningkatkan daya berpikir dalam menganalisa suatu masalah.

2. Bagi Ibu Premenopause

Sebagai pemberi informasi kepada ibu premenopause bagaimana pengetahuan dan sikap ibu dalam menghadapi premenopause sehingga dapat 
mengurangi terjadinya kecemasan pada ibu dan juga memberitahukan kepada ibu halhal yang dapat mempengaruhi terjadinya premenopause.

3. Bagi Kelurahan Baru Ladang Bambu Kecamatan Medan Tuntungan

Hasil penelitian dapat digunakan sebagai sumber informasi tentang ibu premenopause, sehingga pelayanan kesehatan yang efektif dan efisien dapat ditingkatkan dengan memberikan penyuluhanpenyuluhan tentang premenopause.

4. Bagi Institusi Pendidikan Fakultas Ilmu Keperawatan UDA

Sebagai bahan referensi bagi perpustakaan FIK-UDA.

5. Bagi Peneliti Selanjutnya

Sebagai data dasar untuk melakukan penelitian selanjutnya dalam mengembangkan penelitian tentang hubungan pengetahuan dan sikap ibu dalam menghadapi premenopause.

\section{TINJAUAN PUSTAKA}

\subsection{Pengetahuan}

Menurut Notoadmodjo (2012)

Pengetahuan (knowledge) adalah hasil tahu dari manusia, yang sekedar menjawab pertanyaan "what", misalnya apa air, apa manusia, apa alam, dan sebagainya. Dengan kata lain pengetahuan itu dapat menjadi ilmu dengan criteria sebagai berikut : (1) mempunyai objek kajian, (2) metode pendekatan, (3) disusun secara sistematis (4) bersifat universal (mendapat pengakuan secara umum). Sedangkan menurut (Priyoto 2014) pengetahuan adalah hasil dari tahu, dan ini terjadi setelah orang melakukan penginderaan terhadap objek tertentu. Penginderaan terjadi melalui panca indra manusia yakni indra penglihatan, indra pendengaran, indra penciuman, rasa dan raba. Sebagian besar pengetahuan seseorang diperoleh dari mata dan telinga. Pengetahuan atau kognitif merupakan dominan yang sangat penting untuk tindakan seseorang.

Menurut Priyoto (2014) pengetahuan yang tercangkup dalam domain kognitif ada 6 tingkatan yakni:

1. Tahu (know) diartikan sebagai mengingat suatu materi yang telah dipelajari sebelumnya termasuk kedalam pengetahuan tingkat ini adalah mengingat kembali sesuatu yang spesifik dari seluruh bahan yang dipelajari atau rangsangan yang telah diterima.

2. Memahami (Comprehension) diartikan sebagai sesuatu kemampuan untuk menjelaskan secara benar tentang objek yang telah diketahui dan dapat menginterprestasikan materi tersebut secara benar.

3. Aplikasi (application) diartikan sebagi kemampuan untuk menggunakan materi yang telah dipelajari pada kondisi atau situasi real (sebenarnya).

4. Analisis (Analysis) diartikan sebagai kemampuan untuk menjabarkan atau suatu subjek kedalam komponen-komponen, tapi masih di dalam satu struktur organisasi dan masih ada kaitannya satu sama lain.

5. Sintesis (Synthesis) diartikan sebagai kemampuan untuk merangkum atau meletakkan dalam suatu hubungan yang logis 
dari komponen-komponen pengetahuan yang dimiliki.

6. Evaluasi (Evaluation) diartikan sebagai kemampuan untuk meletakkan atau menghubungkan bagian-bagian di dalam suatu bentuk keseluruhan yang baru.

Menurut Priyoto

beberapa faktor yang mempengaruhi kesiapan individu dalam menghadapi perubahan-perubahan yang terjadi dalam dirinya adalah :

\section{a. Karakteristik}

1. Pendidikan

2. Pekerjaan

\section{b. Sosial ekonomi}

Keadaan sosial ekonomi mempengaruhi faktor fisik, kesehatan dan pendidikan. Perempuan yang berasal dari golongan ekonomi rendah cenderung pasrah dan mampu beradaptasi dengan baik saat mengalami menopause. Apabila faktor-faktor tersebut cukup baik, akan mengurangi beban fisiologis, psikologis.

Menurut Notoatmodjo (2010) cara memperoleh pengetahuan dapat dikelompokkan menjadi dua yaitu:

1. Cara Tradisional (Non ilmiah) meliputi: (a) Cara coba salah (Trial and Error) (b) Secara kebetulan terjadi karena tidak disengaja oleh orang yang bersangkutan, (c) Cara kekuasaan atau Otoritas, (d) Berdasarkan pengalaman pribadi, (e) Cara Akal Sehat, (f) Kebenaran melalui wahyu (g) Kebenaran Secara Intuitif (h) Melalui Jalan Pikiran, (i) Induksi (j) deduksi,

2. Cara Modern atau Cara Ilmiah dengan cara yang sistematis, logis dan ilmiah. Cara ini disebut metode penelitian ilmiah atau metodologi penelitian (research methodology).

\subsection{Sikap}

Menurut Azwar (2015) Sikap (attiude) adalah mekanisme mental yang mengevaluasi, membentuk pandangan, mewarnai perasaan, dan akan ikut menentukan kecenderungan perilaku kita terhadap manusia atau sesuatu yang sedang kita hadapi, bahkan terhadap diri kita sendiri. Sikap adalah suatu bentuk evaluasi atau reaksi perasaan. Sedangkan menurut Priyoto (2014) sikap merujuk pada evaluasi individu terhadap berbagai aspek dunia sosial serta bagaimana evaluasi tersebut memunculkan rasa suka atau tidak suka individu terhada isu, ide, orang lain, kelompok sosial dan objek. Sikap pada awalnya diartikan sebagai suatu syarat untuk memunculkan suatu tindakan. Pandangan dan perasaan kita terpengaruh oleh ingatan akan masa lalu, oleh apa yang kita ketahui dan kesan kita terhadap apa yang sedang kita hadapi saat ini.

Menurut Azwar (2015) struktur sikap terdiri atas tiga komponen yang saling menunjang yaitu (a) Komponen Kognitif merupakan representasi apa yang dipercayai oleh individu pemilik sikap, (b) Komponen Afektif merupakan perasaan yang menyangkut aspek emosional, sedangkan (c) Komponen Konatif merupakan aspek kecenderungan berperilaku tertentu sesuai dengan sikap yang dimiliki seseorang.

Menurut Azwar (2015) sikap dan perilaku manusia adalah masalah pengungkapan (assessment) atau pengukuran (measurement) sikap. Adapun dimensi pengukuran sikap: 
(1) sikap mempunyai arah, (2) sikap memiliki intensitas, (3) sikap memiliki keluasan, (4) sikap memiliki konsistensi, (5) sikap memiliki spontanitasnya.

Sifat sikap (a) Sikap positif kecenderungan tindakan adalah mendekati, menyenangi, mengharapkan objek tertentu. (b)Sikap negatif terdapat kecenderungan untuk menjauhi, menghindari, membenci, tidak menyukai objek tertentu (Wawan dan Dewi).

Ciri-ciri sikap: (a) Sikap bukan dibawa sejak lahir melainkan dibentuk atau dipelajari sepanjang perkembangan itu dalam hubungan dengan objeknya. (b) Sikap dapat berubah-ubah. (c) Sikap tidak berdiri sendiri tetapi senantiasa mempunyai hubungan tertentu terhadap suatu objek. (d) Objek sikap itu merupakan suatu hal tertentu tetapi dapat juga merupakan kumpulan dari hal-hal tersebut. (e) Sikap mempunyai segisegi perasaan, sifat alamiah yang membedakan sikap dan kecakapankecakapan atau pengetahuan yang dimilliki orang (Wawan dan Dewi).

Menurut Priyoto (2012) faktor yang mempengaruhi sikap yakni: (a) Sosial merupakan proses penentuan persepsi seseorang terhadap kebutuhan dan kualitas hidupnya dan aspirasi untuk lebih baik lagi, dengan penerapan berbagai informasi yang didesain sebelumnya,

Epidemiologi merupakan hal yang sangat berpengaruh terhadap kualitas hidup seseorang baik langsung maupun tidak langsung, (c) Perilaku dan lingkungan yaitu memisahkan penyebab perilaku dan non perilaku dari masalah kesehatan, mengembangkan penyebab perilaku, melihat important perilaku, melihat changebility perilaku, memilih target perilaku, (d) pendidikan dan organisasi adalah mengidentifikasi kondisi-kondisi perilaku dan lingkungan yang status kesehatan dan kualitas hidup dengan memperhatikan faktor-faktor penyebabnya, (e) administrasi dan kebijakan yaitu merupakan sumber daya dan kejadian-kejadian dalam organisasi yang mendukung atau menghambat perkembangan promosi kesehatan.

\subsection{Siklus Kehidupan Wanita}

Siklus kesehatan wanita serta perubahan yang terjadi pada setiap tahapnya. Dalam kehidupannya, wanita mempunyai tahapan masa yaitu masa bayi, masa kanak-kanak, pubertas, reproduksi, klimakterium, menopause dan senium.

\section{Bayi}

Perubahan pada bayi lahir cukup bulan : (a) Pembentukan genitalia interna telah sempurna. (b) Folikel pada kedua ovarium telah lengkap. (c) Genitalia eksterna telah terbentuk. (d) Minggu pertama dan kedua setelah lahir, bayi masih membawa pengaruh estrogen yang didapat saat dlm kandungan. Pengaruh ini seperti : Epitel vagina relative tebal dan $\mathrm{pH}$ vagina 5 . (e) $1 / 3$ bayi perempuan endoserviksnya tidak terhenti pada ostium uteri eksternum tetapi menutupi juga sebagian dari portio servisis uteri (pseudoerosio kongenitalis).

\section{Kanak-kanak}

Yang khas pada kanak-kanak adalah perangsangan oleh hormon kelamin sangat kecil. Pada masa ini alat-alat genitalnya tidak menunjukkan pertumbuhan yang 
berarti hingga pada permulaan pubertas tetapi pengaruh hipofisis sangat terlihat pada pertumbuhan badannya. Pada masa ini sudah nampak perbedaan antara perempuan dan laki-laki terutama pada tingkah lakunya yang juga ditentukan oleh lingkungan dan pendidikan.

\section{Pubertas/Remaja}

Pubertas merupakan masa peralihan antara masa kanak-kanak ke masa dewasa. Antara kedua masa ini tidak ada batasan yang terlihat, hanya saja pada masa pubertas diawali dengan berfungsinya ovarium dan berakhir pada saat ovarium berfungsi dengan mantap dan teratur. Pada masa ini terjadi perubahan organ-organ fisik secara cepat dan perubahan tersebut tidak seimbang dengan perubahan kejiwaannya dan terjadi kematangan seksual atau alat-alat reproduksi.

\section{Reproduksi}

Masa ini terpenting bagi wanita dan kira-kira berlangsung 33 tahun. Haid pada masa ini paling teratur dan memungkinkan untuk kehamilan. Tetapi setelah usia 40 tahun keatas akan mulai terjadi penurunan kesuburan atau fertilitas.

\section{Klimakterium}

Klimakterium bukan suatu keadaan patologik melainkan suatu masa peralihan yang normal yang berlangsung beberapa tahun sebelum dan sesudah menopause.

\section{Menopause}

Menopause adalah periode berhentinya haid secara alamiah atau suatu masa dimana seorang wanita mengalami perdarahan haid terakhir dan tidak pernah mendapatkan haid lagi. Menopause menyebabkan beberapa perubahan fisik yang dapat mempengaruhi fungsi seksual seorang wanita. Ini semua merupakan akibat dari berkurangnya kadar estrogen dan progesteron.

\subsection{Premenopause}

Premenopause adalah suatu masa menjelang menopause yang terjadi pada umur rata-rata 40-50 tahun Atikah, 2010 dan Harahap dkk, (2018). Menurut Baziad (2003) fase premenopause adalah fase antara usia 40 tahun dan dimulainya fase klimakterik. Fase ini ditandai dengan siklus haid yang tidak teratur yang ditandai dengan perdarahan haid yang memanjang dan ukuran perdarahan banyak dan kadangkadang disertai nyeri.

Tanda-tanda terjadinya Premenopause adalah: (a) menstruasi menjadi tidak teratur (b) "kotoran" haid yang keluar banyak sekali, ataupun sangat sedikit (c) muncul gangguan vasomotoris berupa penyempitan atau pelebaran pada pembuluh- pembuluh darah (d) merasa pusing disertai sakit kepala (e) berkeringat tiada hentinya (f) neuralgia atau gangguan/sakit syaraf.

\subsection{Kerangka Konseptual}

Kerangka konsep dalam penelitian ini terdiri dari satu variable yaitu pengetahuan dan sikap ibu dalam menghadapi pre menopause.

Pengetahuan dan sikap ibu dalam menghadapi premenopause

Gambar 2.1: Kerangka konsep penelitian

\section{METODE PENELITIAN}

3.1 Jenis Penelitian 
Jenis penelitian ini adalah deskriptif untuk mengetahui pengetahuan dan sikap ibu dalam menghadapi premenopause di Kelurahan Baru Ladang Bambu Kecamatan Medan Tuntungan.

\subsection{Lokasi dan Waktu Penelitian}

Penelitian ini dilakukan di Kelurahan Baru Ladang Bambu lingkungan IV Kecamatan Medan Tuntungan pada bulan Juni 2016.

\subsection{Populasi dan Sampel}

Populasi adalah keseluruhan objek penelitian yang akan diteliti (Notoatmodjo, 2012). Populasi dalam penelitian ini adalah seluruh ibu-ibu premenopause di lingkungan IV Kelurahan Baru Ladang Bambu Kecamatan Medan Tuntungan sebanyak 175 orang.

Menurut Notoadmodjo (2012), Sampel adalah objek yang diteliti dan dianggap mewakili seluruh populasi. Dalam penelitian ini jumlah populasi 175 orang, maka sampel yang diambil sebanyak 64 orang, pengambilan sampel menggunakan simple random sampling (pengambilan sampel secara acak sederhana), penentuan besar sampel diperoleh dengan menggunakan rumus:

$$
\begin{aligned}
& \mathrm{n}=\frac{N}{1+N(d)^{2}} \\
& \mathrm{n}=\frac{175}{1+175(0,1)^{2}} \\
& \mathrm{n}=\frac{175}{2,75} \\
& \mathrm{n}=63.636 \rightarrow 64 \text { Responden }
\end{aligned}
$$

Keterangan :

$$
\begin{array}{ll}
\mathrm{n} & =\text { Jumlah sampel } \\
\mathrm{N} & =\text { Jumlah populasi } \\
\mathrm{d} & =\text { nilai tetap }(0,1) .
\end{array}
$$

\begin{tabular}{|c|c|c|c|c|c|c|}
\hline No & Variabel & Definisi & Indikator & Alat ukur & Skala & Hasil \\
\hline 1. & Pengetahuan & $\begin{array}{l}\text { Hasil dari } \\
\text { tahu } \\
\text { seseorang } \\
\text { tentang } \\
\text { premenopause }\end{array}$ & $\begin{array}{l}\text { Defenisi, } \\
\text { tanda dan } \\
\text { gejala, } \\
\text { faktor } \\
\text { resiko, } \\
\text { akibat, } \\
\text { penyebab, } \\
\text { pencegahan. }\end{array}$ & kuesioner & Ordinal & $\begin{array}{l}\text { Baik, } \\
\text { jika } 8- \\
10 . \\
\text { Cukup, } \\
\text { jika 5-7. } \\
\text { Kurang, } \\
\text { jika } 0-4\end{array}$ \\
\hline 2. & Sikap & $\begin{array}{l}\text { Hasil respon } \\
\text { sesorang } \\
\text { terhadap } \\
\text { premenopause }\end{array}$ & $\begin{array}{l}\text { Pandangan, } \\
\text { perasaan, } \\
\text { lingkungan, } \\
\text { kebutuhan }\end{array}$ & kuesioner & Ordinal & $\begin{array}{l}\text { Positif } \\
26-40 \\
\text { Negative } \\
10-25\end{array}$ \\
\hline
\end{tabular}

\subsection{Definisi Operasional}

Populasi adalah keseluruhan objek penelitian yang akan diteliti (Notoatmodjo, 2012).

Tabel 3.1. Defenisi Operasional

\subsection{Definisi Operasional}

Instrument penelitian yang digunakan dalam penelitian ini adalah kuesioner, lembar kuesioner dengan lembar terstruktur untuk melihat hubungan pengetahuan dan sikap ibu dengan kecemasan dalam menghadapi menopause. 
Metode

pengukuran

menggunakan kuesioner yang berisi pengetahuan $\mathrm{ibu}$ terdiri dari 10 kuesioner dengan jawaban benar diberi skore 1 dan jawaban salah diberi skore 0 dengan pilihan jawaban a, b, dan c. Kuesioner yang berisi sikap ibu menggunakan kuesioner terdiri dari 10 pertanyaan dengan jawaban sangat setuju 4, setuju 3, tidak setuju 2, sangat tidak setuju 1 .

\subsection{Metode Pengumpulan Data}

Pengumpulan data akan dilakukan di Lingkungan IV Kelurahan Baru Ladang Bambu Kecamata Medan Tuntungan. Pada saat pengumpulan data peneliti menjelaskan waktu, tujuan, manfaat, dan prosedur pelaksanaan penelitian kepada calon responden yang bersedia berpartisipasi diminta untuk menandatangani lembar persetujuan. Responden yang bersedia diberi lembar kuesioner dan diberi kesempatan bertanya apabila ada pertanyaan yang tidak dipahami. Setelah selesai pengisian, peneliti mengambil lembaran kuesioner kemudian memeriksa kelengkapan data dan jawaban. Jika ada data yang kurang lengkap dapat langsung dilengkapi.

\subsection{Pengolahan Data}

Data-data yang sudah terkumpul diolah dengan menggunakan langkah-langkah sebagai berikut: (1) Editing, (2) Coding, (3) Entri Data, (4) Tabulating.

\subsection{Analisa Data}

Analisa data pada penelitian ini adalah analisa univariat yaitu digunakan untuk mendeskripsikan karakteristik dari variabel penelitian dengan melihat persentasi masingmasing variabel.

\section{HASIL PENELITIAN}

\subsection{Deskripsi Lokasi Penelitian}

Penelitian dilakukan di lingkungan IV Kelurahan Baru Ladang Bambu Kecamatan Medan Tuntungan tahun 2016 dengan batas wilayah sebagai berikut : Sebelah Timur berbatasan dengan Desa Baru Pancur Batu, Sebelah Utara berbatasan dengan Kelurahan Namo Gajah, Sebelah Barat berbatasan dengan Desa Durin Jangak Kecamatan Pancur batu, Sebelah Selatan berbatasan dengan Desa Pancur Batu. Lingkungan IV Kelurahan Baru Ladang Bambu terdiri dari $262 \mathrm{KK}$ dengan jumlah penduduk 940 jiwa, laki-laki 403 jiwa dan perempuan 477 jiwa, di lingkungan IV kelurahan Baru Ladang Bambu terdapat 64 orang ibu premenopause

\subsection{Deskripsi Karakteristik Responden}

Tabel 4.1. Distribusi Frekuensi Karakteristik Responden di Lingkungan IV Kelurahan Baru Ladang Bambu Kecamatan Medan Tuntungan.

\begin{tabular}{llcc}
\hline No. & \multicolumn{1}{c}{ Karakteristik Responden } & Frekuensi (f) & Persentase (\%) \\
& Umur & & \\
1. & $40-45$ tahun & 28 & 43,7 \\
2. & $46-50$ tahun & 36 & 56,3 \\
\hline & Jumlah & $\mathbf{6 4}$ & $\mathbf{1 0 0}$ \\
\hline & Pendidikan & & \\
\hline
\end{tabular}




\begin{tabular}{llrc}
\hline 1. & SD & 29 & 45,3 \\
2. & SLTP & 21 & 32,8 \\
3. & SMU & 11 & 17,2 \\
4. & Perguruan Tinggi & 3 & 4,7 \\
\hline & Jumlah & $\mathbf{6 4}$ & $\mathbf{1 0 0 , 0}$ \\
\hline & Pekerjaan & & \\
1. & PNS & 3 & 4,6 \\
2. & Wiraswasta & 25 & 39,1 \\
3. & IRT & 36 & 56,3 \\
\hline & Jumlah & $\mathbf{6 4}$ & $\mathbf{1 0 0 , 0}$ \\
\hline
\end{tabular}

Pada tabel 4.1 diketahui bahwa dari 64 orang responden umur ibu di lingkungan IV kelurahan Baru Ladang Bambu Kecamatan Medan Tuntungan mayoritas pada kelompok umur 46-50 tahun 36 orang $(56,3 \%)$, pendidikan mayoritas SD 29 orang $(45,3 \%)$, dan pekerjaan mayoritas ibu rumah tangga 36 orang $(56,3 \%)$.

Tebel 4.2. Distribusi Frekuensi Pengetahuan ibu dalam menghadapi Premenopause di Lingkungan IV Kelurahan Baru Ladang Bambu Medan Tuntungan.

\begin{tabular}{|c|c|c|c|}
\hline No. & Pengetahuan & Frekuensi (f) & Persentase (\%) \\
\hline 1. & Baik & 11 & 17,2 \\
\hline 2. & Cukup & 25 & 39,1 \\
\hline 3. & Kurang & 28 & 43,7 \\
\hline & Jumlah & 64 & 100,0 \\
\hline
\end{tabular}

Berdasarkan tabel 4.2 diketahui bahwa pengetahuan ibu dalam menghadapi premenopause mayoritas kurang 28 orang $(43.8 \%)$ dan mayoritas baik 11 orang $(17,2 \%)$.

Tabel 4.3. Distribusi Frekuensi Sikap ibu dalam menghadapi Premenopause di Lingkungan IV Kelurahan Baru Ladang Bambu Medan Tuntungan

\begin{tabular}{llccc}
\hline No. & & Sikap & Frekuensi (f) & Persentase (\%) \\
1. & Positif & & 33 & 51,6 \\
2. & Negatif & 31 & 48,4 \\
\hline & Jumlah & $\mathbf{6 4}$ & $\mathbf{1 0 0 , 0}$ \\
\hline
\end{tabular}

Berdasarkan tabel 4.3 diketahui bahwa sikap ibu dalam menghadapi premenopause mayoritas positif 33 orang $(51,6 \%)$ dan negatif 31 orang $(48,4 \%)$.

\section{PEMBAHASAN}

5.1 Pengetahuan Responden dalam premenopause di Kelurahan Baru Ladang Bambu Kecamatan Medan Tuntungan 
Hasil penelitian kesehatan tentang pengetahuan ibu dalam menghadapi premenopause dapat diketahui bahwa pengetahuan kurang 28 orang $(39,1 \%)$ dan pengetahuan cukup 25 orang $(43,8 \%)$. Penelitian ini sejalan dengan hasil penelitian Yantina (2012) tentang pengetahuan ibu terhadap kecemasan dalam menghadapi menopause di Kecamatan Bebesan Kabupaten Aceh Tengah menunjukkan bahwa dari 86 orang responden mayoritas memiliki pengetahuan kurang 60 orang $(90.9 \%)$.

Pengetahuan biasanya diperoleh dari berbagai pengalaman yang berasal dari berbagai macam sumber seperti media, poster, kerabat dekat, media masa, media elektronik, buku petunjuk, petugas kesehatan dan lainya. Hal ini seperti yang ditemukan pada seluruh ibu premenopause dilingkungan IV Kelurahan Baru Ladang Bambu, bahwa ibu berpengetahuan kurang disebabkan oleh belum adanya penyuluhan kesehatan tentang premenopause.

Menurut Notoatmodjo (2005) menyatakan bahwa informasi dapat diperoleh melalui mata dan telinga. Kurangnya pengetahuan ibu dalam menghadapi premenopause dapat disebabkan minimnya minat ibu untuk mengakses informasiinformasi mengenai kesehatan reproduksi khususnya dalam menghadapi premenopause.

Menurut asumsi peneliti pengetahuan ibu dalam menghadapi premenopause kurang, disebabkan karena tingkat pendidikan yang rendah dan belum pernah mendapatkan informasi tentang premenopause. Hal ini sangat mempengaruhi seseorang dalam mengembangkan nalar dan pengetahuan. Dengan daya nalar yang baik akan memudahkan seseorang untuk meningkatkan pengetahuan. Pengetahuan merupakan salah satu pendorong untuk merubah perilaku atau mengadopsi perilaku yang baru. Pengetahuan tentang premenopause merupakan faktor yang menentukan seseorang dapat menerima terjadinya premenopause sebagai perubahan yang wajar yang akan dialami oleh setiap wanita dan tidak harus menimbulkan kecemasan yang berlebihan. Dukungan keluarga juga sangat diperlukan oleh ibu-ibu premenopause karena perubahan yang akan terjadi akan menimbulkan pikirang yang menganggap dirinya tidak menarik lagi, tidak cantik, bahkan menganggap dirinya tidak bisa member kepuasan kepada suaminya lagi. Pengetahuan juga dipengaruhi oleh pengalaman, jika pengalaman ibu dalam menghadapi premenopause tidak ada maka ibu mempunyai persepsi yang berbeda dalam menghadapi premenopause. Menurut Notoadmojo (2010) pengalaman atau pengetahuan yang dimiliki seseorang merupakan faktor yang sangat berperan dalam menginterprestasikan stimulus yang diperoleh. Pengalaman masa lalu atau apa yang telah didapatkan akan menyebabkan terjadinya interprestasi ibu dalam mengahadapi premenopause.

\subsection{Sikap Responden dalam Menghadapi pre menopause di Kelurahan Baru Ladang Bambu Kecamatan Medan Tuntungan}


Hasil penelitian yang diperoleh dari kuesioner tentang sikap ibu dalam menghadapi premenopause dapat diketahui bahwa sikap ibu mayoritas positif 33 orang $(51,6 \%)$ dan minoritas sikap negatif 31 orang $(48,4 \%)$. Hasil penelitian ini sesuai dengan penelitian Eka (2014) tentang sikap ibu dengan kecemasan menghadapi menopause di Kelurahan Tanggikiki Kecamatan Sipatana Kota Gorontalo, menunjukkan bahwa dari 59 responden sikap ibu mayoritas baik 35 orang $(59,3 \%)$.

Menurut Yantina (2014) sikap adalah determinan perilaku, karena mereka berkaitan dengan persepsi, kepribadian dan motivasi. Sebuah sikap merupakan suatu keadaan siap mental, yang dipelajari dan diorganisasi menurut pengalaman dan yang menyebabkan timbiulnya pengaruh khusus atau reaksi seseorang terhadap orangorang, objek-objek dan situasi-situasi dengan siapa dia berhubungan.

Menurut asumsi peneliti sikap merupakan reaksi atau respon yang masih tertutup dari seseorang terhadap suatu objek. Sikap positif dari ibu yang akan menghadapi premenopause mampu mengalihkan perasaan yang tidak menyenangkan ke hal-hal positif dengan cara melakukan berbagai aktivitas, dan mereka menganggap bahwa hal-hal yang dialami selama premenopause merupakan hal wajar yang akan dialami oleh setiap wanita. Sikap ibu dalam menghadapi premenopause di pengaruhi juga oleh budaya dan lingkungan semakin banyak kegiatan ibu dilingkungan masyarakat maka ibu semakin menyesuaikan diri dengan perubahan yang sedang dialami. Berbeda hal dengan kebanyakan wanita dikota yang sangat cemas dalam menghadapi premenopause, mereka takut akan perubahan-perubahan yang terjadi seperti kulit keriput, gangguan libido, penurunan daya ingat, gangguan tidur, cemas, perubahan emosi, rasa sepi dan lainnya, mereka beranggapan dengan terjadinya premenopause suami mereka tidak menyayangi mereka lagi, maka wanita-wanita kota melakukan berbagai cara untuk mengatasi perubahan-perubahan yang terjadi selama menghadapi menopause seperti melakukan terapi sulih hormon. Maka saran untuk ibu-ibu premenopause tidak perlu takut dalam menghadapi premenopause asalkan kita siap dan dapat mengantisipasinya maka wanita premenopause dapat tetap hidup sehat dan bahagia.

\section{KESIMPULAN \\ Kesimpulan}

Setelah dilakukan penelitian tentang pengetahuan dan sikap ibu dalam menghadapi premenopause di Kelurahan Baru Ladang Bambu Kecamatan Medan Tuntungan, maka dapat disimpulkan pengetahuan ibu dalam menghadapi pre menopouse adalah kurang sedangkan sikap ibu dalam mengahapi premenopause adalah positif.

DAFTAR PUSTAKA

Agus, (2013) Statistik Inferensial Untuk Analisa Data

Kesehatan. Yogyakarta: Nuha medika.

Ali, (2003) Menopause Dan Andomenopause. Jakarta: 
Yayasan bina pustaka Sarwono $\mathrm{P}$.

Atikah, (2010) Menopouse Dan Syndrome Menopause. Yogyakarta: Nuha Medika.

Azwar, (2015) Sikap Manusia Teori Dan Pengukurannya.

Yogyakarta: Pustaka pelajar.

Eka, dkk (2014) Hubungan Pengetahuan Ibu Dengan Kecemasan Menghadapi Menopause Di Kelurahan Tanggikiki Kecam,Atan Sipatana Kota Gorontalo, Jurnal Jurnal keperawatan Universitas Negeri Gorontalo.. Endang, (2008) Menopause, Siapa Takut? Yogyakarta: Kasinus.

Harahap, S., Dalimunthe, R., \& Lubis, M. (2018). PENGARUH BUDAYA ORGANISASI DAN PENERAPAN STANDAR ASUHAN KEPERAWATAN

TERHADAP KINERJA PERAWAT DI RUANG RAWAT INAP RS. MARTHA FRISKA BRAYAN MEDAN. Jurnal Darma Agung, 26(3), 677 - 685. Retrieved from https://jurnal.darmaagung.ac.id/ index.php/jurnaluda/article/vie $\underline{\mathrm{w} / 80}$

Oktevana, (2014) Hubungan Sikap Ibu Premenopause Dengan Perubahan Yang Terjadi
Menjelang Masa Menopause Dikelurahan Woloan 1, Kecamatan Tomohon Barat, Kota Tomohon, Jurnal Keperawatan Fakultas Kedokteran Universitas Sam Ratulangi Manado.

Priyoto, (2014) Teori Sikap Dan Perilaku Dalam Kesehatan. Yogyakarta: Nuha Medika

Putriyani, (2014) Hubungan Pengetahuan Ibu Dengan Kecemasan Menghadapi Menopause Di Kelurahan Tanggikiki Kota Gorontalo, Jurnal keperawatan Universitas Negeri Gorontalo.

Rostiana, (2009) Kecemasan Pada Wanita Yang Menghadapi Menopause, Jurnal Psikologi vol 3, N0. 12009 Jawa Barat.

Notoadmodjo, (2010) Metedologi Penelitian Kesehatan. Jakarta: Rineka Cipta. (2012) Metedologi Penelitian Kesehatan. Jakarta: Rineka Cipta.

Suliswati, dkk (2005), Konsep Dasar Keperawatan Kesehatan Jiwa. Jakarta: EGC

Yantina (2012) Pengetahuan Ibu Terhadap Kecemasan Dalam Menghadapi Menopause di Kecamatan Bebesan Kabupaten Aceh Tengah. 